\title{
Preparation and Characterization of Nanoparticular Systems for Topical Treatment of Ocular Infections
}

\section{Oküler Enfeksiyonların Topikal Tedavisinde Nanopartiküler Sistemlerin Hazırlanması ve Karakterizasyonu}

\author{
Ebru Erdal ${ }^{1 \oplus}$, Yesim Altay Aslan $^{2}{ }^{\oplus}$, Nagihan Ugurlu ${ }^{3}$ \\ ${ }^{1}$ Ankara Yıldırım Beyazıt University, Advanced Technologies Research and Application Center, Ankara, Turkey. \\ ${ }^{2}$ Ufuk University, Faculty of Medicine, Department of Ophthalmology, Ankara, Turkey. \\ ${ }^{3}$ Ankara Yıldırım Beyazıt University, Faculty of Medicine, Department of Ophthalmology, Ankara, Turkey.
}

\section{ABSTRACT}

\begin{abstract}
n this study, the active ingredient of besifloxacin was loaded into PLGA nanoparticles and the usability of the obtained nanoparticles as a controlled drug release system for the treatment of bacterial conjunctivitis was investigated. Besifloxacin was selected because it does not contain a systemic formulation and is effective against both gram-positive and gram-negative pathogens. After topical application, besifloxacin was loaded into PLGA nanoparticles and tested for effectiveness in order to prolong the residence time of besifoxacin. For this purpose, besifloxacin loaded PLGA nanoparticles were characterized and toxicity and in vitro release studies were performed. Nanoparticles were characterized as morphological structure by scanning electron microscopy (SEM), size and charge analysis by Zeta Sizer and physicochemical structure by Fourier Transform Infrared Spectrometry (FTIR). According to the Zeta Sizer results, the nanoparticles have a mean size of $200 \mathrm{~nm}$ and the SEM images support the results. It was determined that $40 \%$ of the initial concentration of besifloxacin active substance was loaded on PLGA nanoparticles as a result of the determination of the amount of drug found in the supernatant. The release pattern of besifloxacin from the nanoparticles was not found to be burst effect but was released in a slower and more controlled manner.
\end{abstract}

\section{Key Words}

PLGA nanoparticles, besifloxacin, drug delivery systems, eye infection.

\section{öz}

\begin{abstract}
Calışmada, PLGA nanopartiküllere besifloksasin etken maddesi yüklenmiş ve elde edilen yapının bakteriyel konjuktivit tedavisi için kontrollü ilaç salım sistemi olarak kullanılabilirliği araştırılmıştır. Besifloksasin, sistemik bir formülasyon içermediği ve hem gram-pozitif hem de gram-negative patojenlere karşı etkili olduğu için seçilmiştir. Topikal uygulama sonrasında, besifoksasinin uygulama bölgesindeki kalım süresini uzatmak amacıyla besifloksasinin nanopartiküllere yüklenmiş ve etkinliği test edilmiştir. Bu amaçla, besifloksasin yüklü PLGA nanopartiküller karakterize edilmiş, toksisite ve in vitro salım çalışmaları yapıımıştır. Nanopartiküller, morfolojik yapısı taramalı elektron mikroskobu, boyut ve yük analizi Zeta Sizer, fizikokimyasal yapısı Fourier Dönüşümü Kızılötesi Spektrometresi (FTIR) ile karakterize edilmiştir. Zeta Sizer sonuçlarına göre nanopartiküllerin ortalama $200 \mathrm{~nm}$ boyutuna sahip olduğu belirlenmiştir ve SEM görüntüleri de sonuçları destekler niteliktedir. Nanopartikül yıkama solüsyonunda bulunan ilaç miktarının belirlenmesi sonucu, başlangıçtaki besifloksasin aktif madde konsantrasyonunun \%40’ının PLGA nanopartiküllere yüklendiği tespit edilmiştir. Nanopartiküllerden besifloksasinin salım profili, ani bir salım şeklinde olmayıp daha yavaş ve kontrollü bir şekilde salındığı görülmüştür.
\end{abstract}

\section{Anahtar Kelimeler}

PLGA nanopartikül, Besifloksasin, ilaç taşıyıcı sistemler, göz enfeksiyonu. 


\section{INTRODUCTION}

u opical drug applications are the most frequently used drug administration in the treatment of superficial eye infections. Topical applications of eye medicines allow the onset of efficacy in a short time after the application, while preventing the development of systemic toxicity. However, the most important limitation of topical drug applications in eye diseases is low level of bioavailability. Because of precorneal factors such as rapid tear turnover, non-productive absorption, and the relative impermeability of the drugs, the bioavailability of topical drugs is very low $[1,2]$.

These low levels of bioavailability require more frequent drop administration to achieve the target therapeutic concentration. This increases the risk of systemic and ocular toxicity. To increase the effectiveness of the agents used in the treatment of ocular surface diseases and to reduce the number of drug administration, prolonging the precorneal stay is one of the most important goals [3].

Ocular activity is closely related to the level of ocular bioavailability of drugs. Increasing the corneal penetration of the drugs and prolonging the precorneal length of time allows the ocular bioavailability to be increased. In the development of a pharmaceutical form of medication, different methods are used to increase the duration of precorneal stay. Various colloidal systems such as inserts, collagen-containing ocular drug delivery systems, liposomes, nanoparticles and nanocapsules have been designed and investigated for improved ocular bioavailability [4].

In recent years, studies have been carried out to develop nanotechnology based drug delivery systems such as microemulsions, nanosuspensions, nanoparticles, solid lipid nanoparticles, niosomes, dendrimers and liposomes in order to increase the solubility of both insoluble and insufficient drugs. Nanoparticular drug delivery systems have been shown to increase the concentration of the drug in the anterior camera by increasing corneal passage [5]. Organic and inorganic structures can be used in the preparation of nanostructures. When the literature was examined, it was seen that the three most commonly used polymers in ophthalmic drug formulations were poly (alkyl cyanoacrylate), polycaprolactone and poly (lactic acid)/poly (lactic-coglycolic acid). In the development of ophthalmic drug delivery system, it is considered that the structure has low toxicity and suitable particle size, allowing sufficient bioavailability [6].

Bacterial conjunctivitis is a bacterial-based ocular eye infection that can affect the individual at every age. Treatment of bacterial conjunctivitis with the use of broad-spectrum antibiotics that are effective against both gram-negative and gram-positive bacteria increases the treatment success especially in resistant cases [7]. For this purpose, topically administered besifloxasin, moxifloxacin, gatifloxacin and azithromycin are available. Besifloxacin is a fluoroquinolone structure antibiotic developed for the topical treatment of ophthalmic bacterial infections. The likelihood of developing resistance due to the lack of systemic form of besifloxacin is much lower than that of other antibiotics. Besifloxacin has higher in vitro activity and the lowest minimal inhibitory concentration against gram-positive pathogens and anaerobes than gram-negative pathogens [8].

As besifloxacin is topically applied, it is formulated with a mucoadhesive polymer, which increases the retention of the drug on the ocular surface in order to prolong the survival time at the site of application. Prolonged administration of the active substance at the site of infection means a high drug concentration and, consequently, more microbial eradication rates. Thus, it is ensured that the biofeedback of the drug is improved and its ocular efficiency is increased [9].

Despite the high concentration on the ocular surface, the lack of targeted dose in the aqueous fluid limits the efficacy of besifloxacin in deep keratitis and anterior segment infections. In the study, PLGA polymer was chosen for the loading of the active ingredient besifloxasin. After topical application, it is aimed to increase the concentration of besifloxacin in deep corneal layers and anterior camera by controlled release from besifloxacin loaded PLGA nanoparticles.

\section{MATERIALS and METHODS}

\section{Materials}

For the preparation of the nanoparticles was used the poly(lactic-co-glycolic acid) and PVA (Polyvinyl alcohol) (Sigma, USA). Besifloxacin, as the model drug, was obtained from Sigma. Human Retinal Microvascular Endothelial Cells (HRMEC) and Cell Systems Complete Medium, Culture Boost, Bac-off which used for the 
preparation of cell culture media were supplied from (Cellsystem, USA). 3-[4,5-dimethylthiazol-2-yl]-2,5diphenyltetrazolium bromide (MTT) used in the MTT assay for the determination of cytotoxicity of nanoparticles was obtained from Acros Organics (New Jersey, US). All reagents were analytical grade and used as received without further purification.

\section{Preparation of Besifloxacin Loaded PLGA Nanoparticles}

Solvent evaporation technique was used to prepare besifloxacin loaded PLGA nanoparticles (Bes-PLGA np.). $100 \mathrm{mg}$ of PLGA and $400 \mu \mathrm{g}$ besifloxacin were dissolved in $4 \mathrm{ml}$ of acetone as organic phase. 1\% PVA solution was used as aqueous phase. The organic phase was emulsified in the aqueous phase by ultrasound probe for 60 s at $70 \%$ amplitude (Bandelin, Sonopuls HD 4200, Germany). The resulting emulsion is poured into 40 $\mathrm{ml}$ of $0.1 \%$ PVA solution. The acetone was removed by continuous stirring the emulsion at $400 \mathrm{rpm}$ for $4 \mathrm{~h}$ on a magnetic stirrer (Daihan, SMHS-6, South Korea). After the acetone was removed from the emulsion, the nanoparticles were collected by centrifugation of the solution at $11000 \mathrm{rpm}$ for $30 \mathrm{~min}$ (Eppendorf, 5804R, USA). The supernatant was removed and the nanoparticles were washed 3 times with distilled water. After nanoparticles was freeze-dried by the lyophilizer, it is stored at $+40 \mathrm{C}$ until re-use. PLGA nanoparticles without besifloxacin were prepared according to the same procedure.

\section{Determination of Besifloxasin Content in the PLGA Nanoparticles}

In order to determine the amount of drug loaded into nanoparticles, there are two methods in the literature, direct and indirect. In this study, indirect method was used to determine the amount of besifloxacin in PLGA nanoparticles. In the indirect method, during the preparation of Bes-PLGA np., the particles were centrifuged and washed 3 times with distilled water. The amount of besifloxacin in the supernatants was determinate by measuring the absorbance at $289 \mathrm{~nm}$ with nanodrop. The obtained result was subtracted from the initial amount of besifloxacin and the amount of drug loaded into the nanoparticles was determined (equation 1) [10].

Encapsulation efficiency $=\left[\frac{(\text { weight of initial total drug-weight of free drug })}{\text { weight of initial total drug }}\right] \times 100$

\section{Characterization of Nanoparticles}

Zeta Sizer (Malvern Instruments, Model 3000 HSA, Malvern, England) was used to determine the hydrodynamic diameter, size distribution and surface charge of PLGA and Bes-PLGA nanoparticles. The nanoparticles were diluted with distilled water at a ratio of $1 / 100$ to a final volume of $2 \mathrm{ml}$ and sonicated to prevent particle aggregation. All measurements were repeated 3 times and the results were evaluated with Zeta Sizer Software (Malvern, UK).

The morphology of the PLGA nanoparticles were determined by using scanning electron microscopy (SEM) (FIB-SEM, TESCAN, GAIA 3). The nanoparticles for SEM analysis were diluted and dropped $(10 \mu \mathrm{L})$ a sample holder and dried under vacuum. Nanoparticles were imaged after being coated with gold by using a coating system (Leica ACE 600).

Infrared (IR) spectra of freeze-dried nanoparticles were obtained with ATR-FTIR (Nicolet ${ }^{\mathrm{TM}}$ IS $^{\mathrm{TM}} 50$ spectrometer (Thermo Fisher Scientific, Madison, WI, USA). Scans were performed between 4000 and $600 \mathrm{~cm}^{-1}$ at a resolution of $4 \mathrm{~cm}^{-1}$. The changes in the chemical structure of PLGA and Bes-PLGA nanoparticles were evaluated with FTIR analysis.

\section{In vitro Besifloxacin Release}

In vitro release studies were carried out in a modified Franz Diffusion Cells. Between the cells of this binary cell system include a dialysis membrane with a pore diameter of $12 \mathrm{kDa}$. 20mg Bes-PLGA nanoparticles were suspended in $5 \mathrm{ml}$ PBS and placed in one cell of a doublecell system, the other cell contained only $5 \mathrm{ml}$ PBS. This system was incubated at $37^{\circ} \mathrm{C}$ with $100 \mathrm{rpm}$ agitating in a shaking incubator (Microtest, Turkey). 500- $\mu$ l samples were withdrawn from the only PBS-containing chamber at predetermined time intervals and fresh PBS in the same volume was added. Samples were analyzed with nanodrop (CLARIO star, LVis Plate 680-101, Germany) at $289 \mathrm{~nm}$. The measurements were performed in 4 parallel and 3 replicates.

\section{Cells}

Human Retinal Microvascular Endothelial Cell Culture (HRMEC) was obtained from Cell systems (Kirkland, WA 98034 USA). Cells were cultured in suspension in Cell Systems Complete Medium supplemented with Culture 
Boost (animal derived growth factors) and Bac-off (antibiotic) (Cell system, USA) at $37^{\circ} \mathrm{C}$ in a balanced air humidified incubator with an atmosphere of $5 \% \mathrm{CO}_{2}$.

\section{Cytotoxicity Assay (MTT)}

MTT assay is generally used to cell cytotoxicity, proliferation or viability. In this study, MTT assay was used to measure the cytotoxicity of besifloxacin, PLGA and BesPLGA nanoparticles by determining of viable HRMEC in culture. HRME cells were seeded to 96-well plates and incubated overnight in a humidified $5 \% \mathrm{CO}_{2}$ incubator at 370C. The nanoparticles and besifloxacin are diluted at certain concentrations $(10,50,100,250,500$ and $1000 \mu \mathrm{g} / \mathrm{ml}$ ) with the cell culture medium. Cells were incubated with nanoparticles for $24 \mathrm{~h}$ under $5 \% \mathrm{CO}_{2}$ atmosphere at 370C. After nanoparticles containing medium was removed, $13 \mu \mathrm{L}$ of MTT solution $(5 \mu \mathrm{g} / \mathrm{ml})$ was added to cells and the cells were incubated at $37^{\circ} \mathrm{C}$ for $4 \mathrm{~h}$. Then, the MTT solution was removed and isopropanol- $\mathrm{HCl}(0,04 \mathrm{M})$ was added to each well. The wells were read at $570 \mathrm{~nm}$ on a micro-plate reader (CLARIO star, Germany) and the percentage viability was calculated. The cells, which are not treated with nanoparticles or

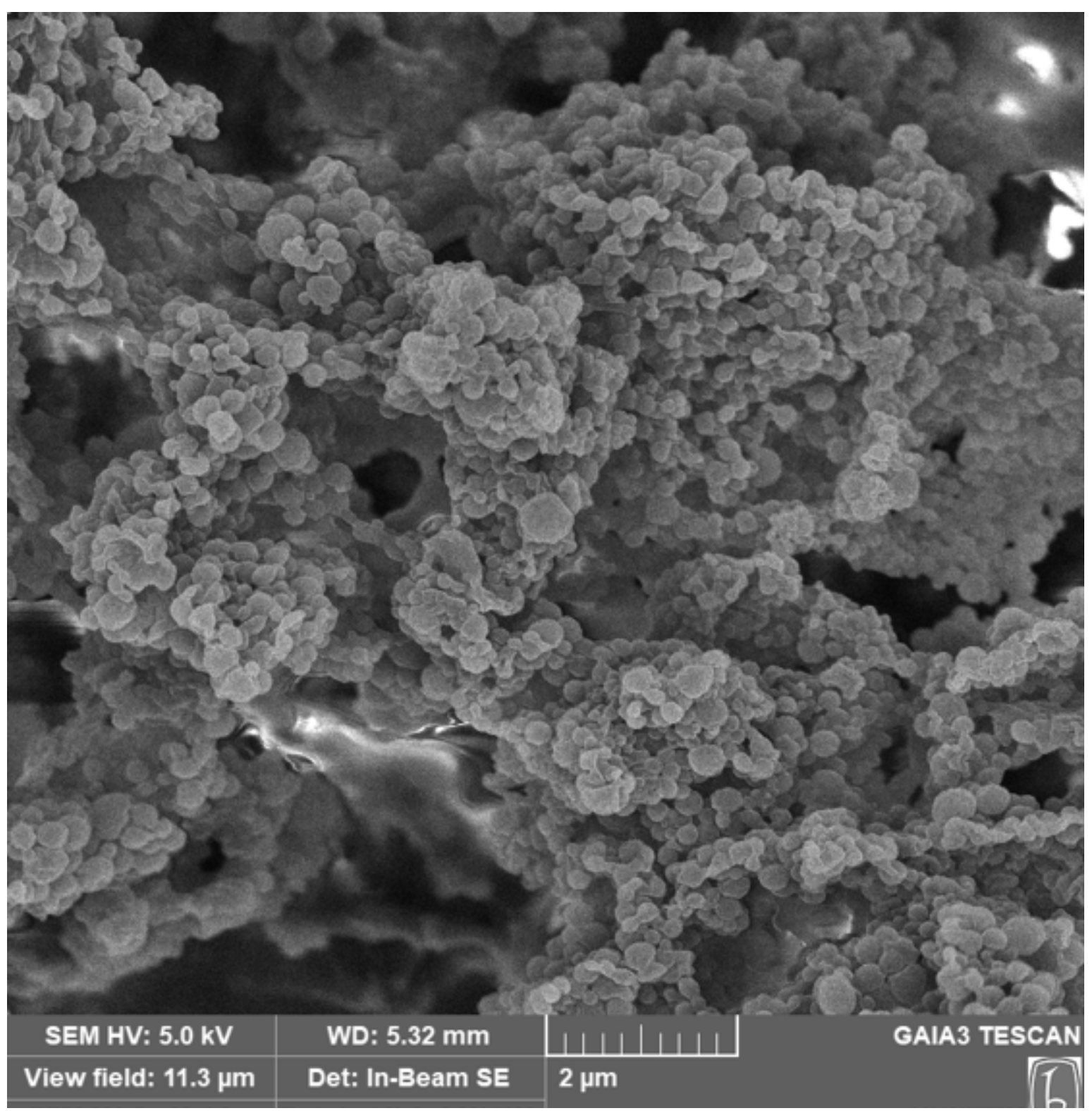

Figure 1. SEM images of PLGA nanoparticles. 
besifloxacin, are the control group and the concentration of these cells is $100 \%$. The viability (\%) was calculated according to the following equation (2):

Cell viability\% $=($ OD570 $($ sample $) / O D 570($ control $)) \times 100$

\section{Antibacterial Test}

The antimicrobial efficiency of the nanoparticles was assessed by comparison with the free drug (besifloxasin), PLGA nanoparticles without besifloxasin and BesPLGA nanoparticles on E. coli as gram-negative bacteria and S. aureus as gram-positive bacteria. The bacterial suspensions used in the study were prepared by suspending a few well-isolated colonies from Nutrient Broth agar plates in Nutrient Broth. Suspensions were incubated at $37^{\circ} \mathrm{C}$ and $100 \mathrm{rpm}$ in a shaking incubator overnight. The suspensions were diluted with the sterile buffer solution and bacteria were inoculated on the agar. Discs of $6 \mathrm{~mm}$ diameter are prepared and placed at regular intervals on the agar. $10 \mu \mathrm{l}$ of test samples at certain concentrations $(50,250,500$ and $1000 \mu \mathrm{g} / \mathrm{ml})$ were impregnated on the discs. The agar plates containing the discs are incubated at $37^{\circ} \mathrm{C}$ overnight. After the incubation, an inhibition zone is comprised of around the discs. The average diameter of the inhibition zone surrounding the disks containing test samples was measured to determine inhibition ( $\mathrm{mm})$.

\section{RESULT and DISCUSSION}

\section{Characterization of Nanoparticles}

PLGA and Bes-PLGA nanoparticles were evaluated in terms of the physicochemical properties, mean diameter, polydispersity index, morphology and zeta potential.

SEM images were used for morphological evaluation of nanoparticles. The SEM images of the PLGA nanoparticles are shown in Figure 1. It is seen that PLGA nanoparticles have a spherical structure and have a homogeneous size distribution. According to the SEM images, the particles have an average particle size of $200 \mathrm{~nm}$.

The mean diameter, polydispersity index and zeta potentials of the nanoparticles were determined by Zetasizer and then the obtained diameter data were compared with the results derived from SEM. The mean

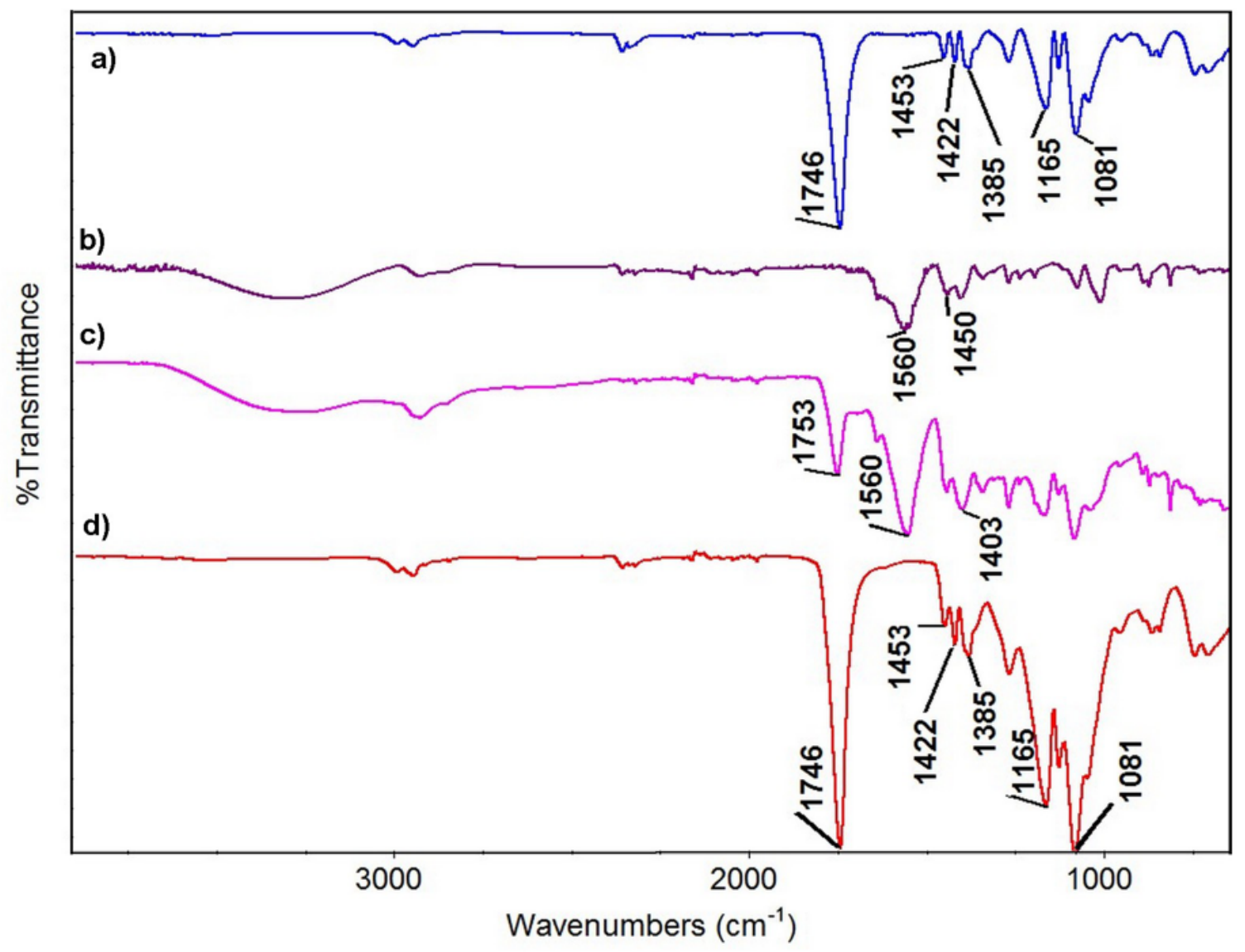

Figure 2. FTIR spectra of PLGA nanoparticles (a), besifloxasin (b), PLGA-besifloxacin physical mixture (c) and Bes-PLGA nanoparticles (d). 
diameter of PLGA nanoparticles is $211 \pm 1,17 \mathrm{~nm}$ and polydispersity index $0,103 \pm 0,02$. The mean diameter of Bes-PLGA nanoparticles is $235 \pm 1,72 \mathrm{~nm}$ and polydispersity index $0,155 \pm 0,01$. When compared to the mean diameter of both nanoparticles, it is seen that the size of Bes-PLGA nanoparticles is larger. This increase in size is due to the loading of the drug to the nanoparticles.

According to zeta potential results, the surface charge of PLGA nanoparticles in PBS pH 7.4 was found to be $-3.46 \pm 1.4 \mathrm{mV}$ and the surface charge of Bes-PLGA np. in PBS pH 7.4 was found to be $-5.16 \pm 0.15 \mathrm{mV}$. The results are consistent with the literature [11]. When the zeta potential of both nanoparticles was evaluated in distilled water, lower surface charge values were obtained. The surface charge of PLGA nanoparticles in distilled water was found to be $-26.25 \pm 1.85 \mathrm{mV}$ [12] and the value of the Bes-PLGA nanoparticles was found to be $-30.75 \pm 1.05 \mathrm{mV}$. In both solutions, it was found that the zeta potential of the drug loaded nanoparticles was lower. The increase in size and zeta potential of Bes-PLGA nanoparticles compared to that of empty PLGA nanoparticles is due to the encapsulation of besifloxacin and the presence of negatively charged structures in its structure. The surface charges of the particles are of high importance in terms of their biodistribution and pharmacokinetic properties. It was determined that proteins bind to the surface of nanoparticles in in vivo applications. Due to the load of proteins, protein binding to the surface of negatively charged nanoparticles occurs at a lower rate [13].
The loading of besifloxacin to PLGA nanoparticles was characterized by FTIR. FTIR result of besifloxacin was compared with that of only PLGA nanoparticles, physical mixture and of freeze-dried nanoparticles (Figure 2). The PLGA nanoparticle sample (Figure 2a) showed peaks such as carbonyl $-\mathrm{C}=\mathrm{O}$ stretching $\left(1746 \mathrm{~cm}^{-1}\right), \mathrm{C}=\mathrm{C}$ stretching $\left(1620 \mathrm{~cm}^{-1}\right),-\mathrm{CH}$ bending $\left(1440-1500 \mathrm{~cm}^{-1}\right)$, C-O stretching $\left(1050-1250 \mathrm{~cm}^{-1}\right)[14,15]$ along with the characteristic peak of besifloxacin (Figure 2b) at 1640 $\mathrm{cm}^{-1}$ (amide) and 1690-1730 $\mathrm{cm}^{-1}$ (C=O of $\mathrm{COOH}$ ) [15]. When the FTIR results of Besifloxacin, physical mixture and freeze-dried nanoparticles were compared, drug peak in freeze-dried nanoparticles were not seen. This can be attributed to the fact that the characteristic peaks of PLGA and besifloxacin in the FTIR spectrum are very close to each other and the concentration of the drug is much lower while the polymer concentration is high. This is in agreement with the results obtained from drug loading studies on some matrices prepared from PLGA polymer in the literature $[16,17]$. This also shows the storage stability of the system.

\section{In vitro Besifloxacin Release}

In order to determine the amount of drug loaded into the nanoparticles was used indirect method, which is based on the calculation of the determination of the amount of drug, which is found to be free in the nanoparticle. It was determined that $40 \%$ of the initial concentration of besifloxacin active substance was loaded

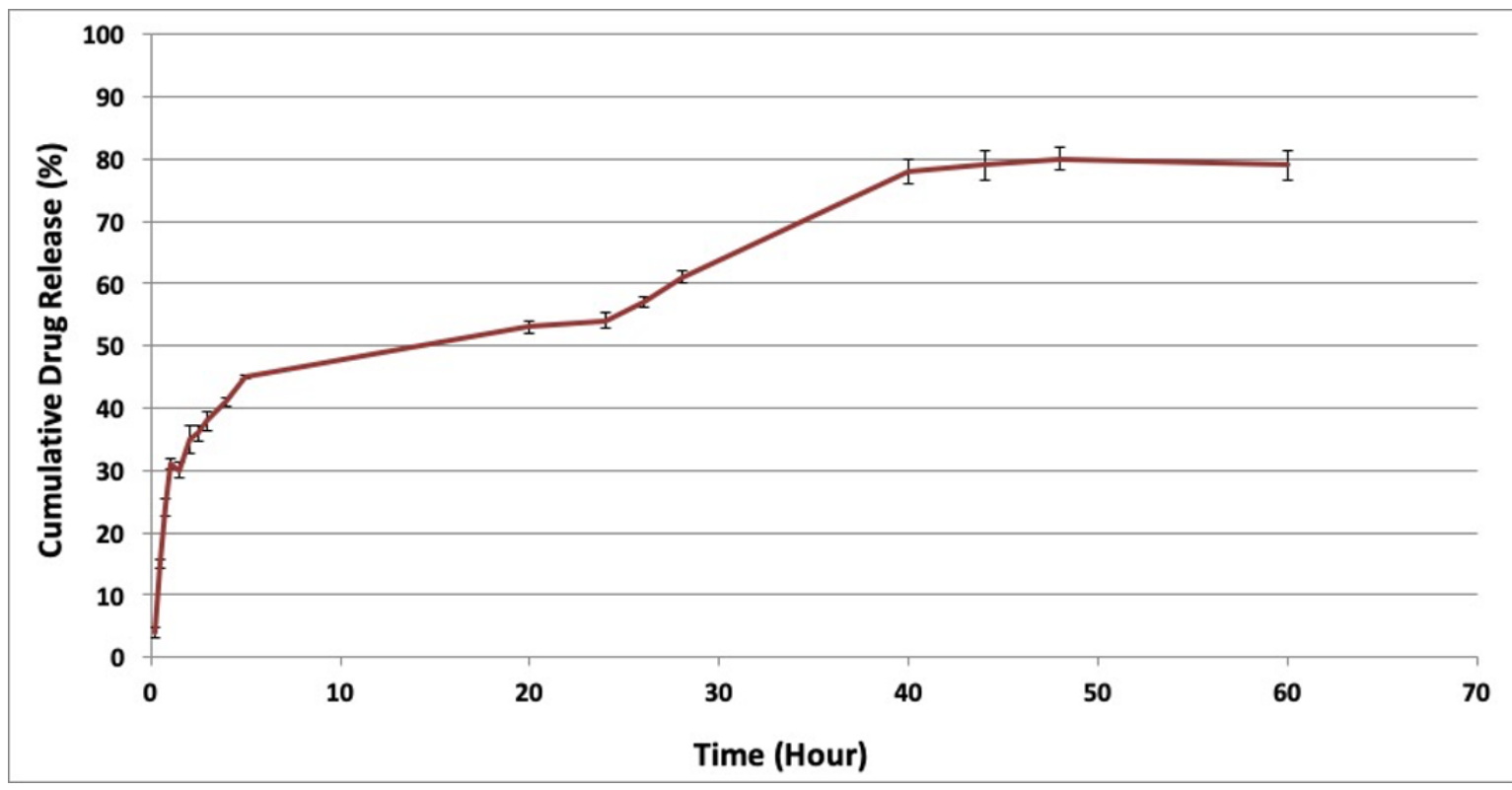

Figure 3. Cumulative drug release of besifloxacin from Bes-PLGA nanoparticles formulation. 


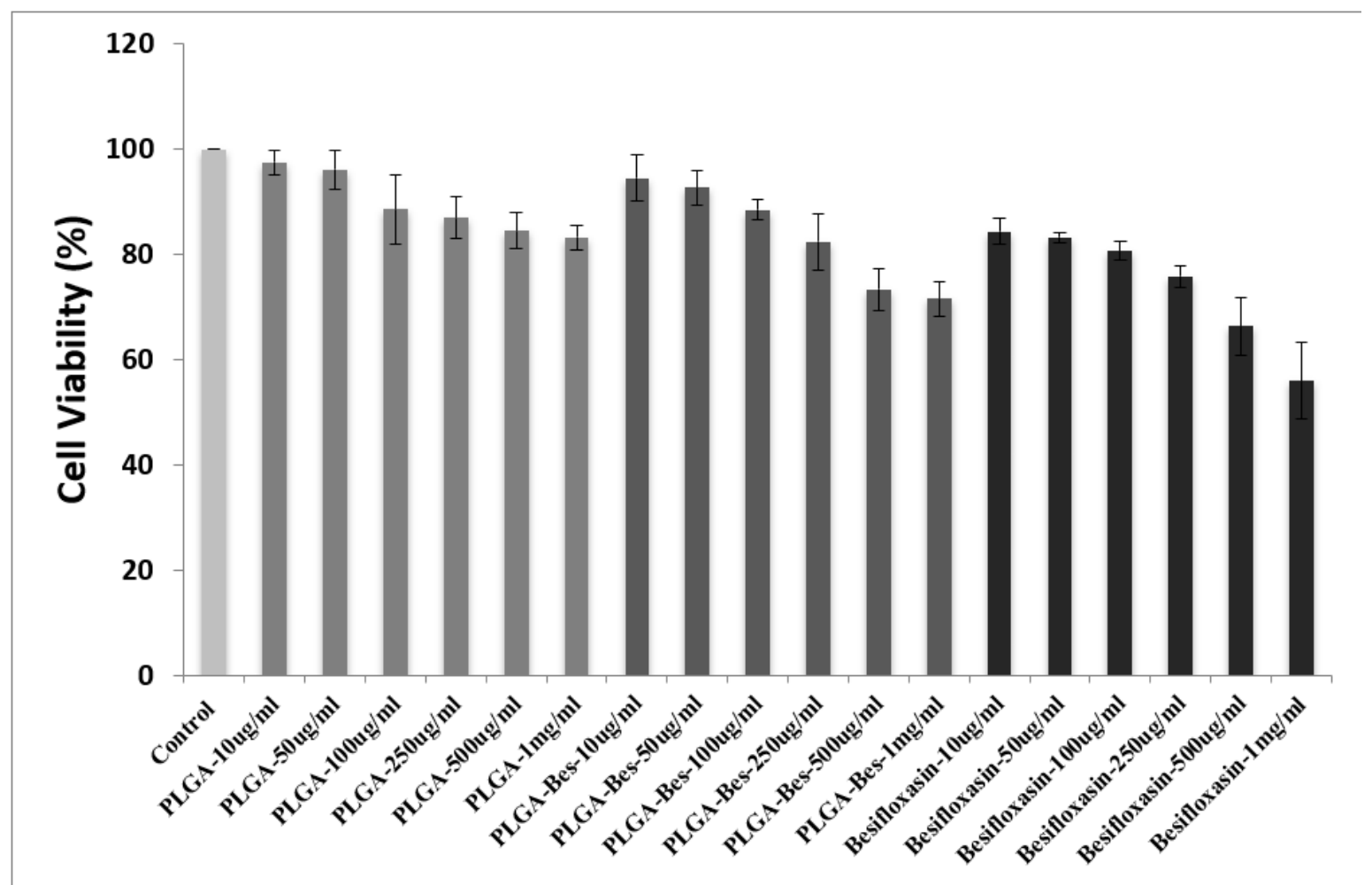

Figure 4. Cytotoxic effect of PLGA NP formulation and besifloxacin against HRME cell line.

on PLGA nanoparticles as a result of the determination of the amount of drug found in the supernatant.

Because of the insufficient protection and the transition of the drug in the eye is directed to the use of longerrelease structures in topical ocular applications. It is aimed to a long-term release by loading besifloxacin into PLGA nanoparticles. The obtained data show that the loading of besifloxacin into PLGA nanoparticles results in a prolonged release. The release profile of besifloxacin from PLGA nanoparticles is shown in figure 3 . The release pattern of besifloxacin from the nanoparticles was not found to be a burst effect, but was released in a slower and more controlled manner. As a result of the study, about $80 \%$ of the besifloxacin loaded into the nanoparticles was showed to be released at the end of 40 hours.

In a study published by Vishakha et al. in 2018, besifloxacin hydrocloride installed in-situ ophthalmic gel formulations prepared and the release profile of besufloxacin was determined. In the study, it was shown that more than $90 \%$ of besifloxasin was released as a result of 8 hours of incubation [18]. Bijit Saha and Rakesh Patel have loaded besifloxacin in niozam in their studies published in 2017 and determined their release profile.
At the end of the 12th hour, approximately $70 \%$ of the besifloxacin loaded into the niozomes was reported to be released [19].

\section{Cytotoxicity Assay (MTT)}

One of the major concerns in the use of pharmaceuticals or nanoparticular systems in biological systems is their toxicity. Drug loaded nanoparticular systems should be able to deliver sufficient amounts of drugs without compromising the viability of the cells. Therefore, cytotoxicity of nanoparticles was evaluated by Human Retina Microvascular Endothelial cells. The viability of the cells was determined for 24 hours on certain concentrations of besifloxacin, empty PLGA, Bes-PLGA nanoparticles.

The viability of the cells treated with empty PLGA np. was decreased due to increased concentration of nanoparticles, but this toxicity was negligible. HRME cells treated with PLGA nanoparticles showed greater than $80 \%$ viability even at the highest concentration [20, 21]. The cytotoxicity of the cells treated with besifloxacin shows an increase due to an increase in drug concentration. Similar results were obtained from cells treated with BesPLGA nanoparticles. However, it was observed that the cell viability at the same concentration was higher when 


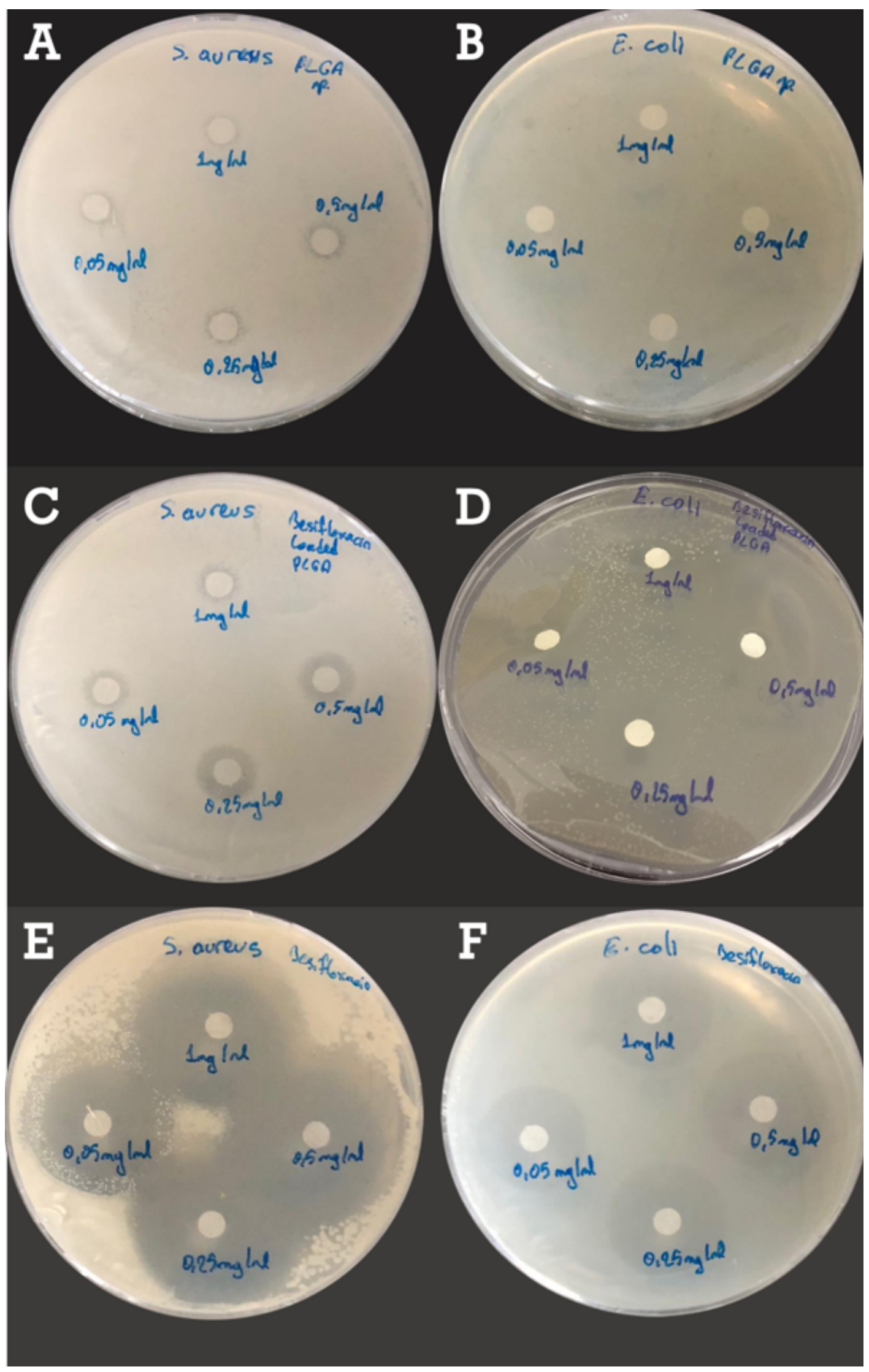

Figure 5. Inhibition zones of Antimicrobial Activity of PLGA np. (A, B), Bes-PLGA np. (C, D) and besifoxacin (E, F) against S. aureus and E. coli. 
compared with the cells treated with besifloxacin only. The cells treated with besifloksasin at a concentration of $100 \mu \mathrm{g} / \mathrm{ml}$ showed $80 \%$ viability, while the viability of cells treated with the same concentration of Bes-PLGA was $90 \%$. Similarly, $55 \%$ viability was observed in cells treated with $1 \mathrm{mg} / \mathrm{ml}$ besifloxasin, while the viability in cells treated with Bes-PLGA particles was 72\% (Figure 4).

\section{Antibacterial Test}

According to the results of disk diffusion method, empty PLGA nanoparticles had no antimicrobial effect against E. coli bacteria but had little effect on $S$. aureus bacteria species at the tested concentrations (Figure 5.A and 5.B). This rather low antimicrobial effect is thought to be due to the fact that the acid medium formed after the cleavage and separation of lactic and glycolic acid may inhibit bacterial growth [22]. Zone diameters of besifloxacin and Bes-PLGA nanoparticles differ according to the bacterial species. The zone diameter of besifloxacin at $1 \mathrm{mg} / \mathrm{ml}$ concentration is approximately $4.5 \pm 0.3$ $\mathrm{cm}$ in $S$. aureus culture and $2.5 \pm 0.2 \mathrm{~cm}$ in $E$. coli culture (Figure 5.E and 5.F). Compared with besifloxacin, there is a decrease in the zone diameter of Bes-PLGA nanoparticles (Figure 5.C and 5.D). In the S. aureous culture, the zone diameter of besifloxasin at a concentration of $0.5 \mathrm{mg} / \mathrm{ml}$ was $3.5 \pm 0.2 \mathrm{~cm}$, while the zone diameter of Bes-PLGA nanoparticles was $1.4 \pm 0.1 \mathrm{~cm}$. This is due to a more controlled release of the drug from the particles and the lower concentration of the drug in the particles. Both besifloxacin and PLGA shows good antibiotic activity against Staphylococcus aureus [18] (Figure 5).

There are animal studies showing that besifloxacin can also be used for the treatment of bacterial keratitis caused by bacterial infection. In the study of Sanders et al., the efficacy of 3 different active substances (besuploxacin, gatifloxacin and moxifloxacin) was investigated for the treatment of keratitis caused by methicillin-resistant Staphylococcus aureus. In rabbit model of keratitis induced by methicillin-resistant S. aureus, it was observed that 10 hours after administration of besifloxasin, the number of bacteria in corneas caused a greater reduction in bacterial count compared to treatment with Gatifloxacin or moxifloxacin [23].

Fluoroquinolones, which are widely used in the treatment of infections, are widely used in the treatment of ocular infections caused by most conjunctivitis-related Gram-positive and Gram-negative bacteria due to the- ir wide spectrum and low toxicity. Fluoroquinolones act by binding and inhibiting the bacteria DNA-gyrase and topoisomerase IV enzyme. Topoisomerase IV and DNA gyrase enzyme inhibition is effective on Grampositive bacteria, while DNA gyrase enzyme inhibition is effective on Gram-negative bacteria [24]. 4 generation fluoroquinolones have been developed. A new generation of fluoroquinolones was developed upon the development of resistance to bacteria against the first developed fluquinolones (Nalidixic acid) [25]. Fourth generation fluoroquinolones have a higher effect on Gram-positive bacteria as both topoisomerase IV and DNA gyrase are highly inhibited [26]. In 2009, Haas et al. showed that besifloxacin was the most effective antibiotic agent against many species of Staphylococcus (S. aureus, S. epidermidis and S. pneumoniae) [27]. Some microorganisms associated with bacterial conjunctivitis have shown resistance to commonly used antimicrobial agents after a certain period of time. In 2010, Haas et al. Found that besifloxacin was more effective against bacteria developing resistance [28].

\section{References}

1. W. Zhang, M.R. Prausnitz, A. Edwards, Modal of transient drug diffusion across cornea, J. Contr. Release., 99 (2004) 241-58.

2. P.K. Indu, R. Smitha, Penetration enhancers and ocular bioadhesive: two new avenues for ophathalmic drug delivery, Drug. Devel. Ind. Pharm., 28 (2002) 353-69.

3. R. Gaudana, H. K. Ananthula, A. Parenky, A. K. Mitra, Ocular drug delivery. The AAPS journal. 12 (2010) 348-360.

4. D.R. Janagam, L. Wu, and T.L. Lowe, Nanoparticles for drug delivery to the anterior segment of the eye, Adv. Drug Deliv. Rev., 122 (2017) 31-64.

5. R. Katara, S. Sachdeva, D.K. Majumdar, Enhancement of ocular efficacy of aceclofenac using biodegradable PLGA nanoparticles: formulation and characterization, Drug Deliv. Translat. Res., 7 (2017) 632-641.

6. H.A. Salama, M. Ghorab, A.A. Mahmoud, M.A. Hady, PLGA Nanoparticles as Subconjunctival Injection for Management of Glaucoma, AAPS PharmSciTech, 18 (2017) 2517-2528.

7. F.S. Mah, C.M. Sanfilippo, Besifloxacin: Efficacy and Safety in Treatment and Prevention of Ocular Bacterial Infections, Ophthalmol. Ther., 5 (2016) 1-20.

8. W. Haas, C.M. Pillar, G.E. Zurenko, J.C. Lee, L.S. Brunner, T.W. Morris, Besifloxacin, a novel fluoroquinolone, has broadspectrum in vitro activity against aerobic and anaerobic bacteria, Antimicrob. Agents and Ch., 53 (2009) 3552-3560.

9. J. Yoshida, A. Kim, K.A. Pratzer, W.J. Stark, Aqueous penetration of moxifloxacin $0.5 \%$ ophthalmic solution and besifloxacin $0.6 \%$ ophthalmic suspension in cataract surgery patients, J. Cataract and Refrac. Surg., 36 (2010) 1499-1502. 
10. V. Arulmozhi, K. Pandian, S. Mirunalini, Ellagic acid encapsulated chitosan nanoparticles for drug delivery system in human oral cancer cell line (KB), Coll. and Surf. B: Biointerfac., 110 (2013) 313-320.

11. H.S. Yoo, K.H. Lee, J.E. Oh, T.G. Park, In vitro and in vivo anti-tumor activities of nanoparticles based on doxorubicinPLGA conjugates, J. Contr. Rel., 68 (2000) 419-431.

12. C. Fonseca, S. Simoes, R. Gaspar, Paclitaxel-loaded PLGA nanoparticles: preparation, physicochemical characterization and in vitro anti-tumoral activity, J. Contr. Rel., 83 (2002) 273-286.

13. S. Honary, F. Zahir, Effect of Zeta Potential on the Properties of Nano-Drug Delivery Systems-A Review (Part 2), Tropical Journal of Pharmaceutical Research, 12 (2013) 265-273.

14. N. Pirooznia, S. Hasannia, A.S. Lotfi, M. Ghanei, Encapsulation of Alpha-1 antitrypsin in PLGA nanoparticles: In vitro characterization as an effective aerosol formulation in pulmonary diseases, J. Nanobiotech., 10 (2012) 1-15.

15. H. Gupta, M. Aqil, R.K. Khar, A. Ali, A. Bhatnagar, G. Mittal, Sparfloxacin-loaded PLGA nanoparticles for sustained ocular drug delivery. Nanomedicine: NBM, 6 (2010) 324-333.

16. A. M. Badawy, A. M. Badawy, A. K. Attia, A. E. Abd-Elaleem, M. M. Abd-Elmoety, S. G. Abd-Elhamid, Spectrophotometric and spectrodensitometric determination of sparfloxacin and besifloxacin hydrochlorides in presence of their peroxide degradation products, Int. J. Pharmac. Analy., 40 (2015) 1254-1268.

17. S.M. Agnihotri, P.R. Vavia, Diclofenac-loaded biopolymeric nanosuspensions for ophthalmic application, Nanomedicine: NBM, 5 (2009) 90-95.

18. W. Vishakha, S. Ravindranath, Formulation Development and Evaluation of $\mathrm{pH}$ Triggered in situ Ophthalmic Gel of Besifloxacin Hydrochloride, J. Drug Deliv. Ther., 8 (2018) 313-321.

19. B. Saha, R. P. Patel, Formulation and evaluation of niosomal in situ gel of Besifloxacin hydrochloride Ocular delivery system, Univer. J. Res., 2 (2017) 82-95.
20. P. Aksungur, M. Demirbilek, E.B. Denkbaş, N. Ünlü, Comparative evaluation of cyclosporine A/HPBCDincorporated PLGA nanoparticles for development of effective ocular preparations, J. Microencaps., 29 (2012) 605-613.

21. C. Fonseca, S. Simoes, R. Gaspar, Paclitaxel-loaded PLGA nanoparticles: preparation, physicochemical characterization and in vitro anti-tumoral activity, J. Control. Rel., 83 (2002) 273-286.

22. K. Dillen, J. Vandervoort, G. V. Mooter, L. Verheyden, A. Ludwig, Factorial design, physicochemical characterisation and activity of ciprofloxacin-PLGA nanoparticles, Internat. Journal Pharmac., 275 (2004) 171-187.

23. M. E. Sanders, Q. C. Moore, E. W. Norcross, A. Shafiee, M. E. Marquart, Efficacy of besifloxacin in a rabbit model of methicilline-resistant Staphylococcus aureus keratitis, Cornea, 28 (2009) 1055-1060.

24. J.M. Blondeau, Fluoroquinolones: mechanism of action, classification, and development of resistance, Surv. Ophthalmol., 49(2004) 73-78

25. G. Alexandrakis, E.C. Alfonso, D. Miller, Shifting trends in bacterial keratitis in south Florida and emerging resistance to fluoroquinolones, Ophthalmology, 107 (2000) 1497-502

26. D.C. Hooper, Fluoroquinolone resistance among Grampositive cocci, Lancet Infect. Dis., 2 (2002) 530-538.

27. W. Haas, C.M. Pillar, G.E. Zurenko, J.C. Lee, L.S. Brunner, T.W. Morris, Besifloxacin, A Novel Fluoroquinolone, Has BroadSpectrum in vitro activity against aerobic and anaerobic bacteria, Antimicrob. Agents Chemother., 53 (2009) 35523560 .

28. W. Haas, C. M. Pillar, C. K. Hesje, C. M. Sanfilippo, T. W. Morris, Bactericidal Activity of Besifloxacin Against Staphylococci, Streptococcus Pneumoniae and Haemophilus Influenzae, J. Antimicrob. Chemother, 65 (2010) 1441-1447. 